\title{
Approach for Highly Active Baker`s Yeast Product from Distilled Yeast Biomass
}

\author{
${ }^{1}$ Fadel M., ${ }^{2}$ Yousif, E.S., Abdelfattah, Abdel kareem ${ }^{2}$, Ola S.S. Mohamed ${ }^{3}$ and Sarra \\ Eid $^{3}$
}

${ }^{1}$ Microbial Chemistry Department Genetic and Biotechnology Division, National Research Centre, 33 El Buhouth St., 12622 Dokki, Giza, Egypt.

${ }^{2}$ Food Science Department, Faculty of Agriculture, Ain Shams University, Subra, Egypt.

${ }^{3}$ Food Science and Technology Department, Food Industry and Nutrition Research Division, National Research Centre, 33 El Buhouth St., 12622 Dokki, Giza, Egypt.

Received: 19 Mar. 2020 / Accepted 30 May 2020 / Publication date: 10 June 2020

\begin{abstract}
Background: Baker's yeast is an essential ingredient of many cereal-based products, and a fundamental element to ensure a reproducible production process and a high quality product to meet the demands of producers and consumers. Its primary role is the production and release of carbon dioxide $(\mathrm{CO} 2)$ gas, through the alcoholic fermentation of sugars, which develops the crumb structure and provides bread loaf volume. Yeast also contributes to the typical bread flavor and is a nutritional complement and a functional ingredient of bread and baking products Result: A study were performed to improve distilled yeast Saccharomyces cerevisiae ( by product of ethanol production from sugar cane molasses) in Egyptian distillery factories to apply as a baker,s yeast. After the yeast biomass was removed at the end of fermentation period for ethanol production .Promising results have been attained for improving the raising power by subjective yeast biomass to successive washing. Furthermore, significant increases in yeast yield, total viable cells, total solid matter (TSM), protein content, trehalose gassing power, accompanied by marked reduction in ash content of cells were gained when the culture conditions of yeast cells were optimized i.e. nitrogen source, phosphorus, magnesium, zinc and biotin as well as $\mathrm{pH}$, temperature and aeration. Comparative studies and chemical analysis on the revived resulting cells have shown that the new product exhibited typical baker's yeast properties with regard to livening power, protein and ash content of cells as well as the number of the active viable cells per gram of the product. The obtained yeast biomass was comparable to standard baker,s yeast .The results were discussed in the light of application feasibilities in production of baker's yeast in alcohol distillation factories. Conclusion: Yeast biomass of S. cerevisiae the byproduct of distilled industry which subjected stress during alcoholic fermentation affected fermentative activity can be activated to use as a baker's yeast in bakery industries. Promising results have been attained for improving the raising power by subjective yeast biomass to successive washing. Furthermore, significant increases in yeast yield, total viable cells, total solid matter (TSM), protein content, trehalose gassing power, accompanied by marked reduction in ash content of cells were gained when the culture conditions of yeast cells were optimized i.e. nitrogen source, phosphorus, magnesium, zinc and biotin as well as $\mathrm{pH}$, temperature and aeration
\end{abstract}

Keywords: distilled yeast biomass, baker,s yeast, culture conditions, gassing power.

\section{Introduction}

Ethanol production is among the oldest technology and is produced commercially by fermentation of cereal grains, molasses or other materials with high starch and/or sugar contents. The fermentation process involves conversion of sugars to alcohol and carbon dioxide by the yeast Saccharomyces cerevisiae. (Fadel et al., 2013) The principal biological agents of fermentation are yeasts belonging to the genus Saccharomyces, which can catalyze alcoholic fermentation to ethanol production. In recent years, yeast strains of $S$. cerevisiae were extensively studied for biotechnological properties enhanced (Souza and Queiroz, 1995). Industrial yeast strains have to resist to the stress conditions rapidly and to adapt easy by modifying their metabolic activities to avoid substantial viability loss. The capability to tolerate various stresses is one of the important criteria to select the

Corresponding Author: Fadel M., Microbial Chemistry Department Genetic and Biotechnology Division, National Research Centre, 33 El Buhouth St., 12622 Dokki, Giza, Egypt.

E-mail:mfade154@yahoo.com 
most effective industrial strains for efficient ethanol fermentation. Fermentation has been used for several thousand years as an effective and low-cost resource to preserve the quality and safety of foods. Apart from this primary role, fermentation adds value and enhances nutritional quality and digestibility through biological enrichment, and provides dietary enrichment through aroma and flavor production and modifying textures of food substrates (Nagodawithan and, Trivedi,1990). The alcoholic fermentation consists of the transformation of carbohydrates in ethanol and carbonic gas through the anaerobic metabolism; however, other substances such as glycerol and acetic acid are produced in smaller amounts (Cook, 1958; Conn and Stumpf, 1972). The microorganisms responsible for the alcoholic fermentation are yeasts, such as Saccharomyces, Schizosaccharomyces, Kluyveromyces, Brettanomyces, Kloeckera and Nadsonia sp. (Prescott and Dunn, 1959; Jones et al., 1981; Moraes, 1981; Lima et al., 1985). Yeasts are a group of unicellular microorganisms most of which belong to the fungi division of Ascomycota and Fungi imperfect (Bekatorou et al., 2006). Yeasts have been used by humans to produce foods for thousands of years. Bread, sake and beer are made with the essential contribution of yeasts, especially from the species. Saccharomyces cerevisiae (Pastor et al., 1980). Because yeasts have a positive image with consumers, they are considered as a safe source of ingredients and additives for food processing (Demain et al., 1998). Preparations of baker's and brewer's yeasts have been available for many years as dietary, nutrient supplements because of their high contents of B vitamins, proteins, peptides, amino acids and trace minerals. Also, yeasts and are often considered as an alternative source of protein for human consumption (Harrison, 1993). Many products are now derived from yeasts and, according to (Stam et al., 1998), about 15$20 \%$ of the global industrial production of yeasts is used for this purpose. Lima et al. (1985) describes the production of antioxidants, aromas, flavors, colors and vitamins by yeasts. Flavor ingredients based on yeast extracts, yeast autolyzates and dried yeast preparations represent the most commercially significant products extracted from yeasts, and are used extensively in the food industry as a source of savoury, roasted, nutty, cheesy, meaty and chicken flavors. In addition, some extracts are specifically enriched in their contents of glutamic acid and nucleotides that function as strong flavor enhancers (Dziezak 1987; Nagodawithana 1992 and Stam et al., 1998). Among the fermentation microorganisms, yeasts are undoubtedly the most important group of microorganisms that are exploited for commercial purposes. Yeasts used in food fermentation processes modify original materials organoleptically, physically and nutritionally and for this they have been used for millennia in bread-making and production of alcoholic beverages (Romano et al., 2006). Baker's yeast is an essential ingredient of many cereal-based products, and a fundamental element to ensure a reproducible production process and a high quality product to meet the demands of producers and consumers. Its primary role is the production and release of carbon dioxide $\left(\mathrm{CO}_{2}\right)$ gas, through the alcoholic fermentation of sugars, which develops the crumb structure and provides bread loaf volume. Yeast also contributes to the typical bread flavor (Cho and Peterson, 2010), and is a nutritional complement and a functional ingredient of bread and baking products. Baker's yeast is required to have several characteristics such as high leavening ability, osmotolerance, freeze tolerance, chemical tolerance, melibiose utilization, good storage ability, and non-agglomeration. Although some of these characteristics are not necessarily required in some methods for bread making, a high leavening ability is the most important characteristic to produce bread of good quality and to save time in bread making. Although baker's yeast is produced under highly aerobic culture conditions to maximize growth and minimize fermentation, bakers wish to minimize growth and maximize the fermentation of baker's yeast for bread making.

This discrepancy suggests that changing the physiological state of commercial baker's yeast enhances its leavening ability. Until now, few reports have been published on a simple and rapid method for enhancing the leavening ability of baker's yeast by changing the physiological state

\section{Materials and Methods}

\section{Microorganisms}

Saccharomyces cerevisiae F-514 strain as a distilled yeast (DY) which was used in ethanol alchohol production from molasses in distillation factories (Egyptian sugar and integrated Industries Company, Hawamdia, Giza- Egypt) and another strain from the same specie; S. cerevisiae F-707 as a baker's yeast (BY) Chemicals Factories, Egyptian sugar and integrated Industries Company. Hawamdia, Giza, Egypt which is used in bread making and other bakery products. The yeasts cultures 
were subcultured on Potato Dextrose Agar medium (PDA), incubated at $34^{\circ} \mathrm{C}$ for $48 \mathrm{hrs}$ and preserved at $4^{\circ} \mathrm{C}$.

\section{Sugar cane molasses}

Sugar cane molasses was obtained from Sugar and Integrated Industries Company, Hawamdia, Giza- Egypt.

\section{Wheat flour (72\% extract)}

Wheat flour was purchased from El-Remaly wheat Milling Company Cairo-Egypt. It was milled from white Australian wheat. Flour was stored in an air tight container and kept until required.

Salt

Sodium chloride salt was purchased from The Egyptian Salts and Minerals Company).

\section{Chemicals and Reagents}

Diethyl ether was obtained from Merck kGaA 64271 Darmstadt, Germany. Potassium sodium tartarate, Tris and D- glucose anhydrous standard grade were procured from BDH Chemicals ltd. Poole, England. Cuper sulfate was obtained from Fluka Chemie AG CH-9470 Buchs. Diammonium sulfate and dinitrosalicylic acid were procured from Panreac Quimica SA E-08211 castellar del valles (Barcelona) Spain. Vitamin biotin was obtained from Hawamdia Factory.Yeast and mould agar medium components and other chemicals used in this study i.e., petroleum ether, sodium acetate, acetic acid, hydrochloric acid, sulphoric acid, urea, zinc sulfate, magnesium sulfate, anthrone, boric acid, trichloroacetic acid and potassium sulfate were analytical grade. Sucrose, glucose, maltose and trehalose were standard grade.

\section{Inoculum preparation}

The inoculum of yeasts was prepared using conical flasks of $500 \mathrm{ml}$ capacity contained broth medium of $(\mathrm{g} / \mathrm{l})$ yeast extract 3 , peptone 5 , malt extract 3 and glucose 10 . After sterilization by autoclave at $121^{\circ} \mathrm{C}$ for $15 \mathrm{~min}$, the cooled flasks were inoculated by a loop of yeast culture and incubated in a rotary shaker $150 \mathrm{rpm}$ adjusted at $34{ }^{\circ} \mathrm{C}$ for $48 \mathrm{hrs}$. The growing yeast was used to inculcate the experimental flasks at $10 \%(\mathrm{v} / \mathrm{v})$.

\section{Molasses medium}

Sugar cane molasses medium was used to propagate distilled yeast strain S. cerevisiaeF-514. This medium was composed of $\mathrm{g} / \mathrm{l}$ molasses 100 (50\% fermentable sugars) and diammonium phosphate, 4 . The $\mathrm{pH}$ was adjusted to 5.0 and the medium was heated for few minutes to be dissolved completely and then was distributed in $500 \mathrm{ml}$ conical flasks contained $100 \mathrm{ml}$. Sterilization was by autoclaving at $121^{\circ} \mathrm{C}$ for 15 minutes. The medium was inoculated with $10 \%(\mathrm{v} / \mathrm{v})$ from the above prepared inoculum. The inculcated flasks were incubated at $30^{\circ} \mathrm{C}$.

\section{Ethanol fermentation}

Ethanol fermentation was carried out by S. cerevisiae F-514in cane molasses medium contained $15 \%(\mathrm{w} / \mathrm{v})$ fermentable sugars supplemented with $0.02 \%$ urea, 0.1 orthophosphoric acid and 0.05 magnesium sulfate and $\mathrm{pH} 4.8$ under anaerobic condition at $34^{\circ} \mathrm{C}$ for $48 \mathrm{hrs}$ under static condition( Fadel et al.,2014). In the end of fermentation, the biomass was harvested by centrifugation at 5000 rpm for 10 minutes.

\section{Washing}

After collecting yeast biomass by centrifugation at $5000 \mathrm{rpm}$ for 10 minutes, it was suspended and soaked in distilled water for $15 \mathrm{~min}$ and then collected by centrifugation. This process was repeated three times.

After every wash process, the yeast biomass was washed, a sample was taken to study the effect of washing process on the fermentation power and the approximate chemical composition. The obtained yeast biomass in the end of fermentation period was harvested by centrifugation, then subjected to study the chemical composition, gassing power and trehalose. 


\section{Urea fortification}

The yeast culture obtained from washing step was growing using molasses medium with adding different concentrations of urea as follows: 1,2 and $4 \mathrm{~g} / 1$. The flasks were incubated for 2 days at 32 ${ }^{\circ} \mathrm{C}$ under shaking at $150 \mathrm{rpm}$. The obtained yeast biomass in the end of fermentation period was harvested by centrifugation, then subjected to study the chemical composition, gassing power and trehalose.

\section{Phosphorous sources}

The yeast biomass obtained from previous step was supplement with different sources of phosphorous as follows: $0.7 \mathrm{ml}$ phosphoric acid (85\%), $0.5 \mathrm{~g}$ di-hydrogen potassium phosphate and 1 $\mathrm{g}$ only urea $+2 \mathrm{~g}$ di-ammonium phosphate were tested to study the effect of phosphorous source on the tested parameters. The flasks were incubated for 2 days at $32{ }^{\circ} \mathrm{C}$ under shaking at $150 \mathrm{rpm}$. The obtained yeast biomass in the end of fermentation period was harvested by centrifugation, then subjected to study the chemical composition, gassing power and trehalose.

\section{Magnesium sulfate addition}

Different concentrations of magnesium sulfate $0.25,0.5$ and $1.0 \mathrm{~g}$ were added to molasses medium contained $2 \mathrm{~g}$ urea, $0.7 \mathrm{ml}$ phosphoric acid. The flasks were incubated for 3 days at $30{ }^{\circ} \mathrm{C}$ under shaking at $150 \mathrm{rpm}$. The obtained yeast biomass in the end of fermention period was harvested by centrifugation, then subjected to study the chemical composition, gassing power and trehalose.

\section{Zinc sulfate addition}

The yeast culture was prepared using molasses medium with adding $2 \mathrm{~g}$ urea, $0.7 \mathrm{ml}$ phosphoric acid, $0.5 \mathrm{~g}$ magnesium sulfate and $0.1 \mathrm{~g}$ zinc sulfate. The flasks were incubated for 3 days at $30{ }^{\circ} \mathrm{C}$ under shaking at $150 \mathrm{rpm}$. The obtained yeast biomass in the end of fermentation period was harvested by centrifugation, then subjected to study the chemical composition, gassing power and trehalose.

\section{Biotin addition}

Different concentrations of biotin $0.01,0.015$ and $0.02 \mathrm{~g}$ by using sterilized one use filter disc diffusion, were added to molasses medium contained $2 \mathrm{~g}$ urea, $0.7 \mathrm{ml}$ phosphoric acid, $0.5 \mathrm{~g}$ magnesium sulfate and $0.1 \mathrm{~g}$ zinc sulfate. The flasks were incubated for 3 days at $30^{\circ} \mathrm{C}$ under shaking at $150 \mathrm{rpm}$. The obtained yeast biomass in the end of fermentation period was harvested by centrifugation, then subjected to study the chemical composition, gassing power and trehalose.

\section{Aeration: (mixing rate)}

Under the optimum concentrations of the previous studied factors as follows: $2.0 \mathrm{~g}$ urea $0.7 \mathrm{ml}$ phosphoric acid, $0.5 \mathrm{~g}$ magnesium sulfate, $0.1 \mathrm{~g}$ zinc sulfate and $0.01 \mathrm{~g}$ biotin. The flasks were incubated for 3 days at $30^{\circ} \mathrm{C}$ under shaking at 150,200 and $250 \mathrm{rpm}$. And different volumes of medium in flask were used as follows: 100,150 and $200 \mathrm{ml}$ per litter. The obtained yeast biomass in the end of fermentation period was harvested by centrifugation, then subjected to study the chemical composition, gassing power and trehalose.

\section{Initial pH}

Under the optimum concentrations of the previous studied factors as follows: $0.7 \mathrm{ml}$ phosphoric acid, $0.5 \mathrm{~g}$ magnesium sulfate, $0.1 \mathrm{~g}$ zinc sulfate and $0.01 \mathrm{~g}$ biotin. The initial $\mathrm{pH}$ of the medium was adjusted to $4,4.5,5$ and 5.5. The obtained yeast biomass in the end of fermentation period was harvested by centrifugation, then subjected to study the chemical composition, gassing power and trehalose.

\section{Temperature of incubation}

The yeast culture was prepared using molasses optimum growth medium as follows: $0.7 \mathrm{ml}$ phosphoric acid, $0.5 \mathrm{~g}$ magnesium sulfate, $0.1 \mathrm{~g}$ zinc sulfate and $0.01 \mathrm{~g}$ biotin. The $\mathrm{pH}$ was adjusted to 5. The medium was incubated at $28,32,36$ and $40{ }^{\circ} \mathrm{C}$. The obtained yeast biomass in the end of 
fermentation period was harvested by centrifugation, then subjected to study the chemical composition, gassing power and trehalose.

\section{Chemical analysis}

Moisture, protein (total nitrogen X 6.25), ash and total lipid content of biomass yield after every improvement step were determined according to the methods described by A.O.A.C. (2012). Total carbohydrate percet, determined as nitrogen free extract (NFE), was calculated by differences as (100 $-($ protein + fat + Ash $)$.

\section{Determination of trehalose content}

Determination of trehalose Sugar Content was according the method described by Trevelyan\& Harrison (1956). Five grams were taken as required from a master sample of yeast stored in the refrigerator. The yeast was suspended in water, a convenient amount of the suspension (containing 100 or $200 \mathrm{mg}$. of yeast) was centrifuged and the supernatant discarded. A duplicate sample of 100 $\mathrm{mg}$. of washed yeast was suspended in $4 \mathrm{ml}$ of $0.5 \mathrm{M}$ TCA and kept for 1 hour in an ice bath with shaking. After centrifuging, the cells were washed once with $4 \mathrm{ml}$. of water, and the combined supernatants made up to $25 \mathrm{ml}$. A portion $(1 \mathrm{ml})$ equivalent to $4 \mathrm{mg}$ of yeast was taken for estimation by anthrone method according to (Brin 1966).

\section{Fermentation power (gassing power)}

One hundred grem of white flour $72 \%$ extract was mixed with $2 \mathrm{~g}$ salt, $1.5 \mathrm{~g} 28 \%$ total solids yeast and 50 to $60 \mathrm{ml}$ of tap water as needed to bring the dough to the desired consistency. The mixing time should not exceed 10 minutes (Parisi, 1981). Volume of forty $\mathrm{ml}$ of the dough were put into a $100 \mathrm{ml}$ glass measuring cylinder, the system was then incubated at $30^{\circ} \mathrm{C}$ and the volume of the dough was measured at time intervals of 15 to $120 \mathrm{~min}$. During the preparation of the dough all the materials were maintained at $30-31^{\circ} \mathrm{C}$ (Borzani, 2004).

Gassing power in glucose, sucrose and maltose solutions:

Gas production was performed by the method described by the Egyptian standard for yeast 2191/2014 of the Egyptian Organization for Standardization Cairo, Egypt, as follows; Ten grams of pure glucose or sucrose were solubilized in $100 \mathrm{ml}$ distilled water at $30^{\circ} \mathrm{C} .1 .0 \mathrm{~g}$ of fresh $28 \%$ total solids yeast was added and left for $30 \mathrm{~min}$. The fermentation power is defined as the gas volume produced by glucose fermentation at $30^{\circ} \mathrm{C}$ for $30 \mathrm{~min}$.

\section{Maltase assay}

Maltase assay was performed by the method described by Jasen et al., (2004) to prepare cell extracts, culture samples were harvested by centrifugation, washed twice with $10 \mathrm{mM}$ potassium phosphate buffer $(\mathrm{pH} 7.5)$ containing $2 \mathrm{mM}$ EDTA, concentrated fourfold, and stored at $-20^{\circ} \mathrm{C}$. Before being assayed, the samples were thawed, washed, and resuspended in $100 \mathrm{mM}$ potassium phosphate buffer ( $\mathrm{pH} 7.5)$ containing $2 \mathrm{mMMgCl} 2$ and $1 \mathrm{~m}$ Mdithiothreitol. Extracts were prepared by sonication with 0.7 -mmdiameter glass beads at $0^{\circ} \mathrm{C}$ in a Ultra sonic cleaner (model Ud150SH3.8L.Q) for $4 \mathrm{~min}$ at 0.5 -min intervals. Unbroken cells were removed by centrifugation (20 min at $36,000 \mathrm{xg}$ ) at $4^{\circ} \mathrm{C}$. The supernatant was used as the cell extract.

Maltase activity was measured with a discontinuous assay. The reaction mixture contained a McIlvain buffer (a combination of $100 \mathrm{mM}$ citric acid and $200 \mathrm{mM} \mathrm{Na}_{2} \mathrm{HPO}_{4}$ ) at pH 6.6 and $120 \mathrm{mM}$ maltose (Okuyama et al., 2001). The reaction was carried out in a total volume of $2 \mathrm{ml}$ at $30^{\circ} \mathrm{C}$ and was started by the addition of cell extract and the reaction was stopped by the addition of $10 \mu 1$ of 1MTris. The samples were analyzed enzymatically for glucose by using the UV method (Biodagnostic kit of Glucose Enzymatic Colorimetric Method). Activities were expressed as micromoles of maltose converted per minute and per milligram of protein (IU protein).

\section{Invertase assay}

The culture medium was centrifuged at $10.000 \mathrm{rpm}$ for 10 minutes at $4^{\circ} \mathrm{C}$. The supernatant was used as crude enzyme source for invertase assay. Invertase activity was assayed as per the method of (Sumner and Howells 1935) using $0.5 \mathrm{ml}$ of sucrose as the substrate in $0.03 \mathrm{M}$ acetate buffer (pH 5.0) and incubated at $45^{\circ} \mathrm{C}$ for 30 minutes. The reaction was terminated by addition of $1 \mathrm{ml}$ of DNS reagent 
and tubes were kept at boiling water bath for 5 minutes. After cooling the tubes at room temperature, $3 \mathrm{ml}$ of distilled water was added in each tube. The intensity of the colour was read at $540 \mathrm{~nm}$ in UV2401 (PC)S UV-Vis recording spectrophotometer (CAT No 206-82201-93). Standard curve was performed with glucose solution. One unit of enzyme activity was defined as the amount of enzyme required for release $1 \mu \mathrm{mol}$ of glucose $/ \mathrm{ml} /$ minute under assay condition. Enzyme activity was expressed in International units (Shankar et al.; 2014).

Invertase activity was calculated using this formula:

\section{Statistical analysis}

$$
\mathrm{IU} / \mathrm{ml}=\text { concentration of glucose } / 0.5 \times 30 \times 0.180
$$

All samples were analyzed $\mathrm{n}$ triplicates and the results wre expressed as mean \pm standard error , except $n=1$ (where $n=$ number of replicates).Analysis was assessed using the statistical Analysis System software .System for Windows (SAS,2008)The significant difference between the mean value were determined by using the analysis of variance(ANOVA) and Duncan,s multiple range test was conducted at a significant level of ( $\mathrm{P} \leq 0.05)$

\section{Results}

Washing and prepare of distilled yeast

Data presented in table (1) show that the washing of distilled yeast biomass resulted in get red of some of metals adsorbed on yeast cells during ethanol fermentation. The removal of some metals led to change in yeast cells constituents as decreased in ash and increased in protein, fat and trehalose.

Table 1: The effect of washing on the chemical composition

\begin{tabular}{llllll}
\hline Washing times & Dry matter & Protein & Ash & Fat & Trehalose \\
\hline Control & $19^{\mathrm{B}} \pm 0$ & $26.77^{\mathrm{D}} \pm 0.33$ & $16.17^{\mathrm{A}} 0.042$ & $2.91^{\mathrm{A}} \pm 0.16$ & $3.56^{\mathrm{A}} \pm 0.198$ \\
One time & $20^{\mathrm{B}} \pm 0$ & $28.74^{\mathrm{C}} \pm 0.76$ & $15.54^{\mathrm{A}} \pm 0.12$ & $3.25^{\mathrm{A}} \pm 0.12$ & $3.77^{\mathrm{A}} \pm 0.18$ \\
Two times & $21^{\mathrm{A}} \pm 0.7$ & $31.63^{\mathrm{B}} \pm 0.25$ & $14.21^{\mathrm{B}} \pm 0.13$ & $3.19^{\mathrm{A}} \pm 0.21$ & $3.79^{\mathrm{A}} \pm 0.050$ \\
Three times & $22^{\mathrm{B}} \pm 000$ & $36.36^{\mathrm{A}} \pm 0.93$ & $12.04^{\mathrm{C}} \pm 0.44$ & $3.32^{\mathrm{A}} \pm 0.26$ & $3.89^{\mathrm{A}} \pm 0.028$ \\
\hline
\end{tabular}

-Results are presented as means for triplicate analysis \pm standard deviation (SD).

-Means in the same column followed by different letters are significantly different $(p \leq 0.05)$

Table 2: The effect of washing on the gassing power and invertase activity

\begin{tabular}{lccccc}
\hline Washing time & \multicolumn{5}{c}{ Gassing power } \\
\cline { 2 - 5 } & Dough** $^{*}$ & $\begin{array}{c}\text { Sucrose } \\
\mathbf{1 0 \%} / \mathbf{w}^{* * *}\end{array}$ & $\begin{array}{c}\text { Glucose } \\
\mathbf{1 0 \%} / \mathbf{w}^{* * *}\end{array}$ & $\begin{array}{c}\text { Maltose 10 } \\
\mathbf{\%} \mathbf{w} / \mathbf{v}^{* * * *}\end{array}$ & $\begin{array}{l}\text { Invertase } \\
\text { activity IU/ml }\end{array}$ \\
\hline Control* & 49 & 30 & 20 & 12 & $1.33^{\mathrm{A}} \pm 0.35$ \\
First time & 58 & 37 & 32 & 14 & $1.25^{\mathrm{A}} \pm 0.085$ \\
Second times & 66 & 44 & 46 & 18 & $1.61^{\mathrm{A}} \pm 0.23$ \\
Third times & 72 & 48 & 52 & 20 & $1.67^{\mathrm{A}} \pm 0.035$ \\
\hline
\end{tabular}

-Results are presented as means for triplicate analysis \pm standard deviation (SD).

-Means in the same column followed by different letters are significantly different $(p \leq 0.05)$.

*Yeast biomass obtained $f$ at fend of alcoholic fermentation.

**After 2 hours $\left(\mathrm{cm}^{3} \mathrm{CO}_{2}\right)$.

*** After 30 minutes $(\mathrm{mmHg} / \mathrm{min})$.

\section{The effect of urea fortification on the chemical composition}

Data presented in table (3) show that addition of urea as nitrogen source to growth medium of yeast enhanced yeast biomass towered baker's yeast futures. However, urea addition at level $2 \mathrm{~g} / \mathrm{l}$ was more suitable than the lower and high levels giving the more demand data as resulted in decreased in ash and increased in protein, fat. Trehalose was raised from 3.89\% before urea addition to be $6.25 \%$. Also addition of urea to the growth medium affect significantly on the total yeast cell numbers table (6). The gassing power of yeast cells in sucrose, glucose and maltose solutions was increased significantly table (4). Invertase activity also gave the high activity when urea concentration was $2 \mathrm{~g} / \mathrm{l}$.

\section{The effect of phosphorous sources}

Data presented in table (5) show that the application of ortophosphoric acid as phosphorus source in fermentation medium was more suitable than both potassium dihydrogen phosphate and di 
ammonium at the same concentration. phosphorous addition mainly resulted in enhancing yeast biomass quality as a baker's yeast .the presented data show that dry matter was better with applying of ortophosphoric acid as phosphorus source in fermentation medium of ortophosphoric acid as phosphors source in fermentation medium (6). The gassing power of yeast cells in sucrose and glucose solution was enhanced significantly comparable to the biomass yield from the pervious growth medium contained no phosphorus table (6). Also an other significant enhanced in invertase activity was achieved (Table 5).

Table 3: The effect of urea fortification on the chemical composition

\begin{tabular}{llllll}
\hline Urea (g\) & Dry matter & Protein & Ash & Fat & Trehalose \\
\hline Control* & $20^{\mathrm{B}} \pm 0$ & $36.36^{\mathrm{A}} \pm 0.93$ & $14.04^{\mathrm{C}} \pm 0.44$ & $3.32^{\mathrm{A}} \pm 0.26$ & $3.89^{\mathrm{A}} \pm 0.028$ \\
$\mathbf{1}$ & $19.94^{\mathrm{A}} \pm 0.085$ & $39.66^{\mathrm{A}} \pm 0.65$ & $11.09^{\mathrm{A}} \pm 0.12$ & $4.29^{\mathrm{B}} \pm 0.53$ & $4.67^{\mathrm{B}} \pm 0.099$ \\
$\mathbf{2}$ & $20.49^{\mathrm{B}} \pm 0.021$ & $42.495^{\mathrm{B}} \pm 0.13$ & $10.52^{\mathrm{B}} \pm 0.028$ & $5.36^{\mathrm{A}} \pm 0.15$ & $6.28^{\mathrm{A}} \pm 0.60$ \\
$\mathbf{4}$ & $18.68^{\mathrm{C}} \pm 0.035$ & $45.98^{\mathrm{C}} \pm 0.31$ & $11.11^{\mathrm{A}} \pm 0.16$ & $5.12^{\mathrm{A}} \pm 0.16$ & $5.21^{\mathrm{A}} \pm 0.42$ \\
\hline
\end{tabular}

-Results are presented as means for triplicate analysis \pm standard deviation (SD).

-Means in the same column followed by different letters are significantly different $(p \leq 0.05)$.

*Yeast biomass obtained $f$ at fend of alcoholic fermentation.

Table 4: The effect of urea on the gassing power and invertase activity

\begin{tabular}{cccccl}
\hline Urea g/l & Dough** & $\begin{array}{c}\text { Gassing power } \\
\text { Sucrose } \\
\mathbf{1 0 \%} / \mathbf{v}^{* * *}\end{array}$ & $\begin{array}{c}\text { Glucose } \\
\mathbf{1 0 \%} / \mathbf{v}^{* * *}\end{array}$ & $\begin{array}{c}\text { Maltose 10 \% } \\
\mathbf{w} / \mathbf{v}^{* * *}\end{array}$ & $\begin{array}{l}\text { Invertase activity } \\
\text { IU/ml }\end{array}$ \\
\hline Control* $^{*}$ & 72 & 48 & 52 & 20 & $1.67^{\mathrm{A}} \pm 0.035$ \\
$\mathbf{1}$ & 81 & 74 & 76 & 26 & $2.33^{\mathrm{A}} \pm 0.113137$ \\
$\mathbf{2}$ & 86 & 76 & 80 & 32 & $2.425^{\mathrm{A}} \pm 0.162635$ \\
$\mathbf{4}$ & 82 & 76 & 79 & 34 & $2.325^{\mathrm{A}} \pm 0.06364$ \\
\hline
\end{tabular}

-Results are presented as means for triplicate analysis \pm standard deviation (SD).

-Means in the same column followed by different letters are significantly different $(p \leq 0.05)$.

* Yeast biomass obtained at end of alcoholic fermentation.

**After 2 hours $\left(\mathrm{cm}^{3} \mathrm{CO}_{2}\right)$

*** After 30 minutes $(\mathrm{mmHg} / \mathrm{min})$.

Table 5: The effect of phosphorous sources on the chemical composition

\begin{tabular}{|c|c|c|c|c|c|}
\hline Phosphorous source & Dry matter & Protein & Ash & Fat & Trehalose \\
\hline Control* & $20.49^{\mathrm{B}} \pm 0.021$ & $42.495^{\mathrm{B}} \pm 0.13$ & $10.52^{\mathrm{B}} \pm 0.028$ & $5.36^{\mathrm{A}} \pm 0.15$ & $6.28^{\mathrm{A}} \pm 0.60$ \\
\hline Phosphoriacid & $22.61^{\mathrm{B}_{ \pm}} 0.69$ & $44.31^{\mathrm{A}} \pm 0.76$ & $7.67^{\mathrm{A}} \pm 0.467$ & $3.315^{\mathrm{A}} \pm 0.12$ & $8.18^{\mathrm{B}} \pm 0.48$ \\
\hline $\begin{array}{l}\text { Dihydrogenpotassium } \\
\text { phosphate }\end{array}$ & $20.45^{\mathrm{A}} \pm 0.07$ & $43.03^{\mathrm{A}} \pm 0.74$ & $7.55^{\mathrm{B}} \pm 0.495$ & $3.47^{\mathrm{A}} \pm 0.049$ & $7.76^{\mathrm{A}} \pm 0.12$ \\
\hline di-ammonium phosphate & $19.95^{\mathrm{A}} \pm 0.353$ & $43.39^{\mathrm{B}} \pm 0.69$ & $13.66^{\mathrm{B}} \pm 0.636$ & $3.46^{\mathrm{A}} \pm 0.198$ & $7.12^{\mathrm{A}} \pm 0.54$ \\
\hline
\end{tabular}

Table 6: The effect of phosphorus on the gassing power and invertase activity

\begin{tabular}{|c|c|c|c|c|c|}
\hline \multirow[b]{2}{*}{ Phosphorus source } & \multicolumn{4}{|c|}{ Gassing power } & \multirow{2}{*}{$\begin{array}{l}\text { Invertase } \\
\text { activity IU/ml }\end{array}$} \\
\hline & Dough** & $\begin{array}{c}\text { Sucrose } \\
10 \% \mathrm{w} / \mathrm{v}^{* * * *}\end{array}$ & $\begin{array}{c}\text { Glucose } \\
10 \% \mathrm{w} / \mathrm{v}^{* * * *}\end{array}$ & $\begin{array}{l}\text { Maltose } 10 \\
\% \mathrm{w} / \mathbf{v}^{* * *}\end{array}$ & \\
\hline Control * & 86 & 76 & 80 & 44 & $1.325^{\mathrm{A}} \pm 0.06364$ \\
\hline phosphoric acid & 94 & 88 & 94 & 49 & $2.08 \mathrm{~A} \pm 0.15556$ \\
\hline Dihydrogen potassium phosphate & 90 & 82 & 90 & 48 & $2.06 \mathrm{~A} \pm 0.09899$ \\
\hline Diammonium phosphate & 92 & 88 & 92 & 42 & $1.61 \mathrm{~B} \pm 0.0566$ \\
\hline
\end{tabular}

-Results are presented as means for triplicate analysis \pm standard deviation (SD).

-Means in the same column followed by different letters are significantly different $(p \leq 0.05)$

*Yeast biomass obtained at end of growth time in molasses medium contained urea as nitrogen source and no phosphorus source.

**After 2 hours $\left(\mathrm{cm}^{3} \mathrm{CO}_{2}\right)$

*** After 30 minutes ( $\mathrm{mmHg} / \mathrm{min})$ 


\section{Effect of magnesium sulfate addition}

Table (7) show Data from the application of magnesium sulfate as magnesium source in fermentation medium. Concentration $0.5 \mathrm{~g} / \mathrm{l}$ was more suitable than both low and high levels. Magnesium addition in growth medium mainly resulted in enhancing yeast biomass quality of a baker's yeast .The presented data show that with applying of magnesium sulfate as magnesium source in fermentation medium. Protein contents in yeast cells was raised as well as the gassing power of yeast cells obtained for dough, sucrose, glucose and maltose solutions were enhanced significantly comparable to the biomass yielded from the previous growth medium contained no magnesium source (Table 8). Also significant enhanced in invertase activity was achieved (Table 8).

Table 7: Effect of magnesium sulfate addition on the chemical composition

\begin{tabular}{clllll}
\hline $\begin{array}{l}\text { Magnesium } \\
\text { sulfate (g】l }\end{array}$ & \multicolumn{1}{c}{ Dry matter } & \multicolumn{1}{c}{ Protein } & \multicolumn{1}{c}{ Ash } & \multicolumn{1}{c}{ Fat } & \multicolumn{1}{c}{ Trehalose } \\
\hline Control * & $22.60^{\mathrm{B}} \pm 0.69$ & $44.31^{\mathrm{A}} \pm 0.76$ & $7.67^{\mathrm{A}} \pm 0.467$ & $3.315^{\mathrm{A}} \pm 0.12$ & $8.18^{\mathrm{B}} \pm 0.48$ \\
$\mathbf{0 . 2 5}$ & $22.79 \pm 0.26$ & $46.91 \pm 0.94$ & $9.79^{\mathrm{B}} \pm 0.22$ & $3.17 \pm 0.085$ & $853^{\mathrm{A}} \pm 0.11$ \\
$\mathbf{0 . 5}$ & $23.89 \pm 0.16$ & $48.09 \pm 0.52$ & $10.48 \pm 0.099$ & $3.22^{\mathrm{A}} \pm 0.11$ & $8.87^{\mathrm{A}} \pm 0.09$ \\
$\mathbf{1 . 0}$ & $22.805 \pm 0.106$ & $47.37 \pm 0.15$ & $10.71 \pm 0.04$ & $3.11 \pm 0.085$ & $7.12^{\mathrm{B} \pm 0.40}$ \\
\hline
\end{tabular}

-Control *

-Results are presented as means for triplicate analysis \pm standard deviation (SD).

-Means in the same column followed by different letters are significantly different $(p \leq 0.05)$.

Table 8: The effect magnesium on the gassing power and invertase activity

\begin{tabular}{|c|c|c|c|c|c|}
\hline \multirow[b]{2}{*}{$\begin{array}{l}\text { Magnesium sulfate } \\
\text { concentrations }\end{array}$} & \multicolumn{4}{|c|}{ Gassing power } & \multirow[b]{2}{*}{$\begin{array}{l}\text { Invertase activity } \\
\text { IU/ml }\end{array}$} \\
\hline & Dough** & $\begin{array}{c}\text { Sucrose } \\
10 \% \mathrm{w} / \mathrm{v}^{* * * *}\end{array}$ & $\begin{array}{c}\text { Glucose } \\
10 \% \mathrm{w} / \mathrm{v}^{* * *}\end{array}$ & $\begin{array}{c}\text { Maltose } 10 \% \\
\text { w/v*** }\end{array}$ & \\
\hline Control $* * *$ & 94 & 88 & 94 & 49 & $2.08 \mathrm{~A} \pm 0.15556$ \\
\hline 0.25 & 98 & 94 & 102 & 46 & $2.19^{\mathrm{B}} \pm 0.01$ \\
\hline 0.5 & 106 & 106 & 118 & 48 & $2.9^{\mathrm{A}} \pm 0.13$ \\
\hline 1.0 & 99 & 89 & 98 & 44 & $2.26^{\mathrm{B}} \pm 0.13$ \\
\hline
\end{tabular}

-Results are presented as means for triplicate analysis \pm standard deviation (SD).

-Means in the same column followed by different letters are significantly different $(p \leq 0.05)$

*Yeast biomass obtained at end of growth time in molasses medium contained urea as nitrogen source and orthophosphoric phosphorus source and no magnesium.

**After 2 hours $\left(\mathrm{cm}^{3} \mathrm{CO}_{2}\right)$

*** After 30 minutes $(\mathrm{mmHg} / \mathrm{min})$.

\section{Effect of zinc supplementation}

Table (9) show Data from the application of zinc sulfate as microelemet source in fermentation medium. Concentration $0.1 \mathrm{~g} / \mathrm{l}$ used in industrial production for bakers yeast was found suitable for enhancing yeast biomass quality of a baker's yeast. The presented data show that with applying of zinc sulfate in fermentation medium. Protein contents in yeast cells was raised as well as the gassing power of yeast cells obtained for dough, sucrose, glucose and maltose solutions were enhanced significantly comparable to the biomass yielded from the previous growth medium contained no zinc source (Table 10) .also significant enhanced in trehalose content as well as invertase activity was achieved (Table 10).

Table 9: The effect of zinc sulfate addition on the chemical composition

\begin{tabular}{clllll}
\hline Zinc sulfate (g\) & Dry matter & Protein & Ash & Fat & Trehalose \\
\hline Control* $^{*}$ & $23.89 \pm 0.16$ & $48.09 \pm 0.52$ & $10.48 \pm 0.099$ & $3.22^{\mathrm{A}} \pm 0.11$ & $8.87^{\mathrm{A}} \pm 0.9$ \\
$\mathbf{0 . 1}$ & $24.28 .2^{\mathrm{A}} \pm 0$ & $48.53^{\mathrm{A}} \pm 0.45$ & $8.59^{\mathrm{A}} \pm 0.30$ & $3.33^{\mathrm{A}} \pm 0.12$ & $9.63^{\mathrm{B}} \pm 0.007$ \\
\hline
\end{tabular}

-Results are presented as means for triplicate analysis \pm standard deviation (SD).

-Means in the same column followed by different letters are significantly different $(p \leq 0.05)$

*Biomass obtained at end of growth time in molasses medium contained urea as nitrogen source and orthophosphoric phosphorus source and magnesium sulfate as magnesium source and no zinc source. 
Table 10: The effect of zinc sulfate addition gassing power and invertase activity

\begin{tabular}{|c|c|c|c|c|c|}
\hline \multirow{2}{*}{$\begin{array}{l}\text { Zinc } \\
\text { sulfate }\end{array}$} & \multicolumn{4}{|c|}{ Gassing power } & \multirow[b]{2}{*}{$\begin{array}{c}\text { Invertase activity } \\
\mathrm{IU} / \mathrm{ml}\end{array}$} \\
\hline & Dough** & $\begin{array}{c}\text { Sucrose } \\
10 \% \text { w/v } * * *\end{array}$ & $\begin{array}{l}\text { Glucose } \\
10 \% \mathrm{w} / \mathrm{v}^{* *}\end{array}$ & $\begin{array}{c}\text { Maltose } \\
10 \% \mathrm{w} / \mathrm{v}^{* *}\end{array}$ & \\
\hline Control & 106 & 106 & 118 & 48 & $2.9^{\mathrm{A}} \pm 0.13$ \\
\hline 0.1 & 116 & 122 & 132 & 52 & $3.85^{\mathrm{A}} \pm 0.035$ \\
\hline
\end{tabular}

-Results are presented as means for triplicate analysis \pm standard deviation (SD).

-Means in the same column followed by different letters are significantly different $(p \leq 0.05)$.

*Yeast biomass obtained at end of growth time in molasses medium contained urea as nitrogen source and orthophosphoric phosphorus source and no magnesium.

**After 2hours $\left(\mathrm{cm}^{3} \mathrm{CO}_{2}\right)$

*** After 30 minutes ( $\mathrm{mmHg} / \mathrm{min})$.

\section{Effect of biotin addition}

Table (11) show Data from the addition of biotin as vitamin activator in fermentation medium .Concentration $0.01 \mathrm{~g} / 1 \mathrm{luse}$ in industrial production for bakers yeast was found suitable for enhancing yeast biomass quality of produced baker's yeast. The presented data show that with applying biotin in fermentation medium. Protein contents in yeast cells was raised as well as the gassing power of yeast cells obtained for dough, sucrose, glucose and maltose solutions were enhanced significantly comparable to the biomass yielded from the pervious growth medium contained no biotin (Table 11) .also significant enhanced in trehalose content as well as invertase activity was achieved (Table 12).

Table 11: Effect of biotin addition on the chemical composition

\begin{tabular}{clllll}
\hline Biotin (glI) & Dry matter & Protein & Ash & Fat & Trehalose \\
\hline Control* $^{*}$ & $24.28 .2^{\mathrm{A}} \pm 0$ & $48.53^{\mathrm{A}} \pm 0.45$ & $8.59^{\mathrm{A}} \pm 0.30$ & $3.33^{\mathrm{A}} \pm 0.12$ & $9.63^{\mathrm{B}} \pm 0.007$ \\
$\mathbf{0 . 0 1}$ & $25.84 \pm 0.057$ & $48.86^{\mathrm{B}} \pm 0.198$ & $7.94^{\mathrm{A}} \pm 0.48$ & $3.31^{\mathrm{A}} \pm 0.049$ & $11.42^{\mathrm{C}} \pm 0.035$ \\
$\mathbf{0 . 0 1 5}$ & $25.48 \pm 0.11$ & $48.55^{\mathrm{B}} \pm 0.64$ & $8.63^{\mathrm{A}} \pm 0.18$ & $3.41^{\mathrm{A}} \pm 0.13$ & $10.44^{\mathrm{A}} \pm 0.12$ \\
$\mathbf{0 . 0 2}$ & $23.95^{\mathrm{A}} \pm 0.92$ & $48.205^{\mathrm{A}} \pm 0.56$ & $8.75^{\mathrm{A}} \pm 0.636$ & $3.4^{\mathrm{A}} \pm 0.085$ & $10.805^{\mathrm{B}} \pm 0.12$ \\
\hline
\end{tabular}

-Results are presented as means for triplicate analysis \pm standard deviation (SD).

-Means in the same column followed by different letters are significantly different $(p \leq 0.05)$.

*Yeast biomass obtained at end of growth time in molasses medium contained urea as nitrogen source and orthophosphoric phosphorus source and no magnesium.

Table 12: Effect of biotin addition on gassing power in dough and solutions of glucose, sucrose and maltose as well as invertase activity

\begin{tabular}{|c|c|c|c|c|c|}
\hline \multirow[b]{2}{*}{$\begin{array}{c}\text { Biotin } \\
\text { concentrations }(\mathrm{g} / \mathrm{L})\end{array}$} & \multicolumn{4}{|c|}{ Gassing power } & \multirow[b]{2}{*}{$\begin{array}{c}\text { Invertase activity } \\
\text { IU/ml }\end{array}$} \\
\hline & Dough** & $\begin{array}{c}\text { Sucrose } 10 \% \\
w / v^{* * *}\end{array}$ & $\begin{array}{c}\text { Glucose } \\
10 \% \mathrm{w} / \mathbf{v}^{* * *}\end{array}$ & $\begin{array}{c}\text { Maltose } \\
10 \% \mathrm{w} / \mathbf{v}^{* * *}\end{array}$ & \\
\hline 0.01 & 128 & 136 & 146 & 52 & $3.025^{\mathrm{A}} \pm 0.007$ \\
\hline 0.015 & 126 & 122 & 138 & 50 & $3.075^{\mathrm{A}} \pm 0.13$ \\
\hline 0.02 & 112 & 116 & 124 & 46 & $3^{\mathrm{A}} \pm 0.01$ \\
\hline
\end{tabular}

-Results are presented as means for triplicate analysis \pm standard deviation (SD).

-Means in the same column followed by different letters are significantly different $(p \leq 0.05)$.

*Yeast biomass obtained at end of growth time in molasses medium contained urea as nitrogen source and orthophosphoric phosphorus source and magnesium sulfate as magnesium source and zinc sulfate as zinc source and no biotin source.

**After 2 hours $\left(\mathrm{cm}^{3} \mathrm{CO}_{2}\right)$

*** After 30 minutes $(\mathrm{mmHg} / \mathrm{min}$

\section{Effect of initial pH incubation}

The presented data in Tables $(13,14)$ show that $S$. cerevisiae giving comparable data could grew well in $\mathrm{pH}$ range from 4.5-5.5. In industrial production low $\mathrm{pH}$ value of growth medium preferable as is not sutable for bacterial contamination. The obtained data can be discussed on the light of hydrogen ions are very important in yeast cell physiology since variations in both extracellular and intracellular $\mathrm{pH}$ can have a dramatic influence on growth and metabolism of yeast cells . 
Table 13: Effect of initial pH on the chemical composition on the biomass of yeast yield

\begin{tabular}{clllll}
\hline Initial pH & Dry matter & Protein & Ash & Fat & Trehalose \\
\hline $\mathbf{4 . 0}$ & $222.44^{\mathrm{B}} \pm 0.078$ & $47.89^{\mathrm{A}} \pm 0.02$ & $8^{\mathrm{B}} \pm 0.099$ & $3.62^{\mathrm{A}} \pm 0.057$ & $9.25^{\mathrm{A}} \pm 0.099$ \\
$\mathbf{4 . 5}$ & $25.84 \pm 0.057$ & $48.86^{\mathrm{B}} \pm 0.198$ & $7.94^{\mathrm{A}} \pm 0.48$ & $3.31^{\mathrm{A}} \pm 0.049$ & $11.42^{\mathrm{C}} \pm 0.035$ \\
$\mathbf{5}$ & $25.93^{\mathrm{C}} \pm 0.085$ & $49.31^{\mathrm{D}} \pm 0.29$ & $7.77^{\mathrm{A}} \pm 0.04$ & $3.45^{\mathrm{A}} \pm 0.04$ & $11.525^{\mathrm{B}} \pm 0.07$ \\
$\mathbf{5 . 5}$ & $23.42^{\mathrm{C}} \pm 0$ & $48.13^{\mathrm{B}} \pm 0.33$ & $7.84^{\mathrm{A}} \pm 0.14$ & $3.69^{\mathrm{A}} \pm 0.057$ & $10.915^{\mathrm{B}} \pm 0.06$ \\
\hline
\end{tabular}

-Results are presented as means for triplicate analysis \pm standard deviation (SD).

-Means in the same column followed by different letters are significantly different $(p \leq 0.05)$.

Table 14: Effect of initial $\mathrm{pH}$ yeast growth on the biomass of yeast yield gassing power in dough and solutions of glucose, sucrose and maltose as well as invertase activity

\begin{tabular}{|c|c|c|c|c|c|}
\hline \multirow[b]{2}{*}{ Initial pH value } & \multicolumn{4}{|c|}{ Gassing power } & \multirow[b]{2}{*}{$\begin{array}{c}\text { Invertase activity } \\
\text { IU } / \mathbf{m l}\end{array}$} \\
\hline & Dough* & $\begin{array}{c}\text { Sucrose } \\
10 \% \mathrm{~m} / \mathrm{v}^{* *}\end{array}$ & $\begin{array}{c}\text { Glucose } \\
10 \% \text { w/v** }\end{array}$ & $\begin{array}{c}\text { Maltose } 10 \% \\
w / v^{* *}\end{array}$ & \\
\hline 4.0 & 85 & 136 & 130 & 130 & $7.21^{\mathrm{C}_{ \pm}} 0.035$ \\
\hline 5.0 & 132 & 154 & 146 & 104 & $7.33^{\mathrm{B}} \pm 0.13$ \\
\hline 5.5 & 126 & 152 & 144 & 100 & $7.55^{\mathrm{A}} \pm 0.04$ \\
\hline
\end{tabular}

-Results are presented as means for triplicate analysis \pm standard deviation (SD).

-Means in the same column followed by different letters are significantly different $(p \leq 0.05)$.

*After 2 hours $\left(\mathrm{cm}^{3} \mathrm{CO}_{2}\right)$.

**After 30 minutes (mmHg/mi.).

Effect of incubation temperature on the chemical composition on the biomass of yeast yield

Growth of bakers yeast under optimum temperature is important to yield good quality biomass (Sanderson, 1985) G.W. increase in dry Yeast product for baking industry. Cereal Foods World .30, 770-775. More suitable results was achieved when S. cerevisie F-514 was incubated at $32^{\circ} \mathrm{C}$ than other temperatures, dry matter, protein content as well as trehalose were high when S. cerevisie F-514 was incubated at $32^{\circ} \mathrm{C}$. On the other hand ash was decreased in the final biomass. The fermentative power of the product were enhanced.

Table 15: Effect of incubation temperature on the chemical composition on the biomass of yeast yield

\begin{tabular}{clllll}
\hline Temperature $^{\mathbf{0}} \mathbf{C}$ & Dry matter & Protein & Ash & Fat & Trehalose \\
\hline $\mathbf{2 8}$ & $25.84 \pm 0.057$ & $48.86^{\mathrm{B}} \pm 0.198$ & $7.94^{\mathrm{A}} \pm 0.48$ & $3.31^{\mathrm{A}} \pm 0.049$ & $11.42^{\mathrm{C}} \pm 0.035$ \\
$\mathbf{3 2}$ & $26.57^{\mathrm{B}} \pm 0.13$ & $49.04^{\mathrm{A}} \pm 0.73$ & $7.52^{\mathrm{B}} \pm 0.12$ & $3.36^{\mathrm{A}} \pm 0.12$ & $11.91^{\mathrm{A}} \pm 0.50$ \\
$\mathbf{3 6}$ & $25.57^{\mathrm{A}} \pm 0.21$ & $47.29^{\mathrm{A}} \pm 0.19$ & $8.10^{\mathrm{A}} \pm 0.24$ & $3.38^{\mathrm{A}} \pm 0.099$ & $11.13^{\mathrm{B}} \pm 0.22$ \\
$\mathbf{4 0}$ & $2217.1^{\mathrm{C}} 0.14$ & $45.36^{\mathrm{B}} \pm 0.83$ & $8.12^{\mathrm{A}} \pm 0.62$ & $3.43^{\mathrm{A}} \pm 0.14$ & $8.65^{\mathrm{B}} \pm 0.11$ \\
\hline
\end{tabular}

-Results are presented as means for triplicate analysis \pm standard deviation (SD).

-Means in the same column followed by different letters are significantly different $(p \leq 0.05)$.

Table 16: Effect of temperature of yeast growth on the biomass of yeast yield gassing power in dough and solutions of glucose, sucrose and maltose as well as invertase activity

\begin{tabular}{|c|c|c|c|c|c|}
\hline \multirow[b]{2}{*}{ Temperature $^{\circ} \mathrm{C}$} & \multicolumn{4}{|c|}{ Gassing power } & \multirow[b]{2}{*}{$\begin{array}{c}\text { Invertase activity } \\
\mathrm{IU} / \mathrm{ml}\end{array}$} \\
\hline & Dough* & $\begin{array}{c}\text { Sucrose } \\
10 \% \mathrm{w} / \mathrm{v}^{* *}\end{array}$ & $\begin{array}{c}\text { Glucose } \\
10 \% \mathrm{w} / \mathrm{v}^{* *}\end{array}$ & $\begin{array}{l}\text { Maltose } 10 \\
\% \mathrm{w} / \mathrm{v}^{* *}\end{array}$ & \\
\hline 28 & 132 & 152 & 144 & 82 & $5.485^{\mathrm{A}} \pm 0.14849$ \\
\hline 32 & 138 & 156 & 156 & 88 & $5.565^{\mathrm{B}} \pm 0.3889$ \\
\hline 36 & 124 & 104 & 126 & 82 & $4.76^{\mathrm{C}_{ \pm}} 0.08485$ \\
\hline 40 & 114 & 94 & 112 & 68 & $4.00^{\mathrm{D}} \pm 0.056569$ \\
\hline
\end{tabular}

-Results are presented as means for triplicate analysis \pm standard deviation (SD).

-Means in the same column followed by different letters are significantly different $(p \leq 0.05)$.

*After 2 hours $\left(\mathrm{cm}^{3} \mathrm{CO}_{2}\right)$.

** After 30 minutes $(\mathrm{mmHg} / \mathrm{m}$.).

\section{Effect of shaking speed during yeast growth}

Oxygen is an important growth factor for bakkers yeast to yield biomass because providing a substrate for respiratory enzymes during aerobic growth to biosynthesis sterols and unsaturated fatty 
acids shaking can improve oxygen transfer and consequently yeast growth .The above presented data ( Table 17 ).

Table 17: Effect of shaking speed during yeast growth on the biomass of yeast yield chemical composition

\begin{tabular}{|c|c|c|c|c|c|}
\hline $\begin{array}{c}\text { Shaker speed } \\
\text { rpm }\end{array}$ & Dry matter & Protein & Ash & Fat & Trehalose \\
\hline 100 & $23.7^{\mathrm{A}} \pm 0.27$ & $45.8^{\mathrm{A}} \pm 0.93$ & $10.42^{\mathrm{A}} \pm 0.12$ & $3.46^{\mathrm{B}} \pm 0.11$ & $8.495^{\mathrm{A}} \pm 0.06$ \\
\hline 150 & $26.57^{\mathrm{B}} \pm 0.13$ & $49.04 \pm 0.73$ & $7.52^{\mathrm{B}} \pm 0.12$ & $3.36^{\mathrm{A}} \pm 0.12$ & $11.91 \pm 0.50$ \\
\hline 200 & $27.65^{\mathrm{A}} \pm 0.05$ & $50.24^{\mathrm{B}} \pm 0.8$ & $7.41^{\mathrm{A}} \pm 0.23$ & $3.35^{\mathrm{A}} \pm 0.18$ & $12.15^{\mathrm{C}} \pm 0.08$ \\
\hline
\end{tabular}

-Results are presented as means for triplicate analysis \pm standard deviation (SD).

-Means in the same column followed by different letters are significantly different $(p \leq 0.05)$.

Table 18: Effect of shaking speed during yeast growth on the biomass of yeast yield gassing power in dough and solutions of glucose, sucrose and maltose as well as invertase activity incubation gassing power and invertase activity

\begin{tabular}{|c|c|c|c|c|c|}
\hline \multirow[b]{2}{*}{ Mixed speed rpm } & \multirow[b]{2}{*}{ Dough* } & \multicolumn{2}{|c|}{ Gassing power } & \multirow[b]{2}{*}{$\begin{array}{c}\text { Maltose } 10 \% \\
w / v^{* *}\end{array}$} & \multirow[b]{2}{*}{$\begin{array}{c}\text { Invertase activity } \\
\text { IU/ml }\end{array}$} \\
\hline & & $\begin{array}{c}\text { Sucrose } \\
10 \% \mathrm{w} / \mathrm{v}^{* *}\end{array}$ & $\begin{array}{c}\text { Glucose } \\
10 \% \mathrm{w} / \mathrm{v}^{* *}\end{array}$ & & \\
\hline 100 & 123 & 126 & 124 & 106 & $8.45^{\mathrm{A}} \pm 0$ \\
\hline 150 & 138 & 156 & 156 & 134 & $8.58^{\mathrm{A}} \pm 0.02$ \\
\hline 200 & 142 & 168 & 172 & 108 & $7.77^{\mathrm{B}} \pm 0.078$ \\
\hline
\end{tabular}

-Results are presented as means for triplicate analysis ¥standard deviation (SD).

-Means in the same column followed by different letters are significantly different $(p \leq 0.05)$.

*After 2 hours $\left(\mathrm{cm}^{3} \mathrm{CO}_{2}\right)$.

**After 30 minutes ( $\mathrm{mmHg} / \mathrm{min}$.)

Table 19: comparison of obtained yeast biomass and standard baker's yeast

\begin{tabular}{lcc} 
Constant & Standard baker's yeast* & Obtained biomass \\
Total viable cell cfu/g 28 \% solids & $1.2 \times 10^{9}$ & $1.22 \times 10^{9}$ \\
Total solids \% & $27-30$ & 27.65 \\
Protein & $48-52$ & 50.24 \\
Phosphorus & $3-5$ & 3.60 \\
Ash \% & $<8$ & 7.41 \\
Trehalose \% & $10-14$ & 12.15 \\
Total carbohydrates \% & $36-42$ & 39.75 \\
\hline
\end{tabular}

*Harison (1967)

\section{Discussion}

Distilled yeast biomass obtained at end of ethnologenic fermentation was low fernmentative activity as it was subjected to sever conduction during fermentation. Also it contain high ash and low total viable cells and low protein as well as low phosphorus. Washing did not affect total viable cells of yeast biomass significantly on the yeast cell numbers but enhanced somewhat the gassing power of yeast cells in sucrose and glucose solution (Fadel and Foda, 2001). Invertase activity was enhanced but not significantly by repeated washing table (2) Strain growth enhancement Bakers yeast have about 7-7.5\% nitrogen of their dry weight. Yeast cannot fix nitrogen therefore, urea is act as good nitrogen source a commonly widely utilized as a cheap nitrogen source in industrial fermentation for production of bakers yeast (Campbll 1988) .phosphate content of Baker's yeast cells accounts for around 3-5 \% of dry weight mostly in the form of orthophosphate) (Obaid et al. (1996). Phosphorus is present in nucleic acids and phospholipids and therefore is essential for yeast growth. Orthophosphric acid are common source of phosphorus in yeast growth medium. it acts as a substrate and effector of many enzymes, including those involved in energy regulation (Okorokov et al., 1980 ) .Magnesium is an absolute requirement for yeast growth and present in the cells at round $0.3 \%$ of dry weight where it plays essential structural and metabolic functions (Walker 1994). Transphosphorlylation enzymes have a strict defense on $\mathrm{Mg}^{2+}$ ion as do enzymes involved in synthesis, expression and translation of genetic information (Aiking and Tempest, 1976). Trace level of zinc are essential for yeast growth. Zinc deprivation in baker's yeast prevent budding and arrests cells in G1phase of the cell cycle. Zinc 
requirements for the growth of the yeast cannot be met by other metal ions. Zinc is essential for the structure and function of many enzymes (Zhao and Eide 1996). Trehalose is a di polymer is very important in shelf life especially in compressed yeast (Gomaa et al., 2017). The obtained data can be discussed on the light of There are organic compounds required in very low concentrations for specific catalytic or structural roles in yeast but are not utilized as energy sources Biotin is vital metabolic functions as component of coenzymes, as it serve as a cofactor in crboxylase- catalyzed reactions (Koser, 1968). S.A. Vitamins requirements of Bactria and Yeast. Similar data was reported by Abdel Nasser et al. (2017). Yeast generally grow very well when culture medium $\mathrm{pH}$ is between 46 ( Jones and Green, 1984)Growth of bakers yeast under optimum temperature is important to yield good quality biomass (Sanderson,1985). Increase in dry yeast product for baking industry. Cereal Foods World. 30,770-775. More suitable results was achieved when S. cerevisie F-514 was incubated at $32^{\circ} \mathrm{Cthan}$ other temperatures .Dry matter, protein content as well as trehalose were high when $S$. cerevisie $\mathrm{F}-514$ was incubated at $32^{\circ} \mathrm{C}$. On the other hand ash was decreased in the final biomass . The fermentative power of the product were enhanced, and this due to the rising of biomass contents of dry matter, protein content and trehalose (Gelinas et al., 1989). Saving oxygen is importance of for yeast growth and yield quality. Yeast could assimilate more of nitrogen source to gave high, protein product, dry matter and trehalose as wellas low ash content in the presence of adequate oxygen. On the other. The obtained yeast biomass reflect positively on the fermentation power in dough and solution of glucose, sucrose and maltose Table (18). The obtained data agree with that obtained by Fatma et al. (2012) and Fadel and Foda, 2001).

\section{Conclusion}

Yeast biomass of $S$. cerevisiae the by product of distilled industry which subjected stress during alcoholic fermentation affected fermentative activity can be activated to use as a baker's yeast in bakery industries. Promising results have been attained for improving the raising power by subjective yeast biomass to successive washing. Furthermore, significant increases in yeast yield, total viable cells, total solid matter (TSM), protein content, trehalose gassing power, accompanied by marked reduction in ash content of cells were gained when the culture conditions of yeast cells were optimized i.e. nitrogen source, phosphorus, magnesium, zinc and biotin as well as $\mathrm{pH}$, temperature and aeration

\section{References}

Abdel Nasser, A.Z.O., M. Fadel, M. Hamad and H.F. El-sharkawy, 2017. Effect of nitrogen sources and vitamins addition on Baker,s yeast fermentation activity. Egyptian Sugar Journal, 9:57-66.

Aiking, H. and D.W. Temper, 1976. Growth and physiology of Candida utilis NcYc321 in potassium chemostat culture. Archive of Microbiology, 108:117-124.

A.O.A.C., 2012.Official Methods of Analysis of the Association of Official Analytical.

Borzani, W., 2004. Measurement of the gassing power of baker, yeast correlation between the dough volume and incubation time. Brazilian Archive of Biology and Technology, 47 (2):213-217.

Brin, M., 1966.Transketol: clinical aspects in: Colowick, S.P. and Kaplin, N.O (eds. Methods of Enzymology, 9, Academic Press, 506-514.

Campbll, I., 1988. Standard media for cultivation of yeast. In yeast practical Approach ted I Campll and J.H .Duffs. 277- 279 IRL press, Oxford and Washington.

Cho, I.H., and D.G. Peterson, 2010. Chemistry of bread aroma: A review. Journal of Food Sci. Biotechnol., 19:575-82.

Conn, E. E., and P.K. Stump, 1972. Manual de Bioquímica. São Paulo: Editora Edgard Blucher Ltda., 420.

Cook , A.H .,1958. The Chemistry and Biology of Yeasts. New York: Academic press, 763.

Demain, A. L., H.J. Phaff, and C.P. Kurtzman, 1998. The industrial and agricultural significance ofyeasts. In: Kurtzman CP, Fell JW (eds). The yeasts - a taxonomic study, 4th eds. Elsevier, Amsterdam, 13-19.

Dziezak, J.D., 1987. Yeast and yeast derivatives. Applications. Food Technol., 41:122-125

Evangelista, J., 1989. Tecnologia de Alimentos. Rio de Janeiro. Livraria Atheneu, 652. 
Fadel, M. and M.S. Foda, 2001. A Novel approach for production of highly active baker's yeast from biomass yeast, a by-product of ethanol production industry, Online J. Biological Sci., 1(7): 614620.

Fadel, M., A.Z. Abdel Nasser, M. Makawy, M.S. Hsona, and A.M. Abdel-Aziz, 2014. Study on Recycling of Vinasse in Ethanol Fermentation and Application in Egyptian distillery Factory .African Journal of Biotechnology, 10 (53):11071- 11083.

Fadel, M., Abeer A. Keera, Foukia E. Moufi and K. Tarek, 2013. High level Ethanol from Sugar Cane Molasses by Anew Thermotolerant Saccharomyces cervisiae Strain in industrial Scale Biotechnology Research International, ID253286 6 pages.

Fatma, A., M.H.A. Shams El-Din, and M. Fadel, 2012. Perspectives for appropriating distilled yeast to be used in bakery. International J. Academic Research, 4(4):11-16.

Gelinas, P., G. Fiset, A. Le Duy, and J. Goulet, 1989. Effect of growth conditions and trehalose content on cryotolerance of bakers yeast in frozen doughs. Applied environmental Microbiology, 55(10): 2453-2459.

Gomaa A., Nadia, A. Nassar, A.H. Yehia, A.A. Mahmoud, and F. Mohamed, 2017. Characteristics of storage stability for different Saccharomyces cerevisiae strains .International Journal of Biological, Food, Veterinary and Agricultural Engineering,11(5): 385-390.

Harison, J.S., 1967.Aspects of commercial yeast production. Process Biotechnology,2, 41-45.

Jansen, M.L., P. Daran-Lapujade, J.H. de Winde, and M.D. Piper, 2004. Prolonged maltose-limited cultivation of Saccharomyces cerevisiae selects for cells with improved maltose affinity and hypersensitivity. Appl. Enviro. Microbiol., 70(4):1956-63.

Jones, R.P. and P.F. Green field, 1984. A review of yeast ionic nutrition 1- Growth and fermentation requirements. Process Biochemistry, 4:48-60.

Jones, R.P., N. Pamment, and D.P.F. Greenfield, 1981. Alcohol Fermentation by Yeasts: The Effect of Environmental and other Variables. Process Biochemistry, 42-49.

Koser, S.A., 1968. Vitamins requirements of Bactria and Yeast. Chartes C Thomas. Spring field .Illinois. USA.

Lima, U.A., E. Aquarone and W. Borzani, 1985. Biotecnologia, Tecnologia das Fermentações. Ed. Edgard Blücher, 1: 285.

Moraes, J.O.F., 1981. FermentaçãoAlcoólica. Curso de Especialização do Álcool-ITEP. Recife.

Nagodawithana, T.W. and N. Trivedi, 1990. Yeast selection for baking, in Yeast Strain Selection (ed. e.J. Panchal), Marcel Dekker, New York, 139-84.

Nagodawithana, T.W., 1992. Yeast derived flavors and flavor enhancers and their probable mode of action. Food Technol., 46:138-144.

Obaid , U., J. Mohns, and M. Rizzi,1996. Dynamics of orthophosphate in yeast cytoplasm Biotechnology Letters, 18,461-466. et al Aiking, H. and Tempest, D.W.1976) Growth and physiology of Candida ulilisNCYC321in potassium chemostat culture Archives of Microbiology, 108:117-124.

Okorokov, L.A., L.P. Lichko, and I.S. Kulaev, 1980. Vacules main compartement of potassium, magnesium and phosphate ions in Saccharomyces carlsbergensis cells . Journal of Bacteriology .144: 661- 665 .

Parisi, F., 1981. An Evolution of two simple methods for measurement of fermenting power of baker,s yeast. J. pure and Applied Chemistry.53:603-610.

Pastor, R.G., R.P. Torrado, G.A. Elena, and M. Emilia, 2011.Ch11: Recent Advances in Yeast Biomass Production. In: Matovic, D. (ed.. Biomass Detection, Production and Usage. ISBN: 978-953-307-492-4,

Prescott, S.C. and C.G. Dun, 1959. Industrial Microbiology. New York: McGraw. Hill Book. P945.

Romano, P., A. Capece and L. Jespersen, 2006. "Taxonomic and Ecological Diversity of Food and Beverage Yeasts" In: Querol, A. and Fleet, G. H. (eds). Yeasts in Food and Beverages. Springer-Verlag, Berlin, Heidelberg

SAS, 2008. System for Windows (Statistical Analysis System) version9.2Cary, USA: SAS Institute Inc.

Shanker, T., P. Thangamathi, R. Rama and T. Sivakumar, 2014.Characterization of invertase from Saccharomyces cerevisiae Mk obtained from today sample. J. Bioprocceing and Chemical Engeneerig, 2(1):1-6. 
Sanderson, G.W., 1985. Increase in dry Yeast product for baking industry. Cereal Foods World, 30:770-775.

Souza, C.M. and L.A. Queiroz, 1995. Flocculation and fermentation capacity of strains of Saccharomyces stored at Mycotheca-URM I. Boletin Micológico, 10(1-2): 89-95.

Stam, H., M. Hoogl, and C. Laane, 1998. Food flavors from yeast. In: Wood, B. J. (ed. Microbiology of fermented foods, Vol. 2, $2^{\text {nd }}$ edn. Blackie, London, 505-542.

Sumner, J.B. and S.F. Howell, 1935.A method for determination of saccharase activity. J. Biological Chemistry, 106:51-54.

Trevelyan, W.E. and J.S. Harrison, 1956.Studies on yeast metabolism 7-yeast carbohydrate fraction. Separation from nuclecic acid. Analysis and behavior during anaerobic fermentation. Biochemical Journal, 63(1):23-33.

Walker, G.M., 1994.The role of magnesium in biotechnology. Critical Reviews in Biotechnology, 14:311-354

Zaho, H., and D. Eide, 1976. The ZRT2 gene encodes the low affinity zinc transporter in Saccharomyces cerevisiae J. Biological Chemistry, 271(12):23203-23210. 